\title{
The growth of plants and indigenous bacterial community were significantly affected by cadmium contamination in soil-plant system
}

\author{
Yunyan Du ${ }^{1,2}$, Dawei Zhang ${ }^{1,3}$, Dinggang Zhou ${ }^{1,3}$, Lili Liu ${ }^{1,3}$, Jinfeng Wu ${ }^{1,3}$, Hongsong Chen ${ }^{4}$, Decai Jin ${ }^{2,4^{*}}$ (D) and
} Mingli Yan ${ }^{1,3^{*}}$

\begin{abstract}
Concentrations of heavy metals continue to increase in soil environments as a result of both anthropogenic activities and natural processes. Cadmium (Cd) is one of the most toxic heavy metals and poses health risks to both humans and the ecosystem. Herein, we explore the impacts of $\mathrm{Cd}$ on a soil-plant system composed of oilseed rapes (Brassica napus and Brassica juncea) and bacteria. The results showed that $\mathrm{Cd}$ accumulation within tissues of two species of oilseed rapes enhanced with increasing concentrations of $\mathrm{Cd}$ in soils, and $\mathrm{Cd}$ treatment decreased their chlorophyll content and suppressed rapeseeds growth. Meanwhile, $\mathrm{Cd}$ stress induced the changes of antioxidative enzymes activities of both B. napus and B. juncea. Response to $C d$ of bacterial community was similar in soil-two species of oilseed rapes system. The impact of $\mathrm{Cd}$ on the bacterial communities of soils was greater than bacterial communities of plants (phyllosphere and endophyte). The a-diversity of bacterial community in soils declined significantly under higher $\mathrm{Cd}$ concentration $(30 \mathrm{mg} / \mathrm{kg}$ ). In addition, soil bacterial communities composition and structure were altered in the presence of higher $\mathrm{Cd}$ concentration. Meanwhile, the bacterial communities of bulk soils were significantly correlated with $\mathrm{Cd}$, while the variation of rhizosphere soils bacterial communities were markedly correlated with $\mathrm{Cd}$ and other environmental factors of both soils and plants. These results suggested that $\mathrm{Cd}$ could affect both the growth of plants and the indigenous bacterial community in soil-plant system, which might further change ecosystem functions in soils.
\end{abstract}

Keywords: Cd, Bacterial community, Oilseed rape, Soil, Phyllosphere, Endophyte

\section{Introduction}

Heavy metals (HMs) in soils have become a serious environmental issue due to their poisonousness and bioaccumulation within the food chain. They can deteriorate soil quality, reduce food safety, and threaten human health (Li et al. 2014). Moreover, these metals are not degraded by chemical or biological methods and are persistent in

\footnotetext{
*Correspondence: dcjin@rcees.ac.cn; ymljack@126.com

1 School of Life Sciences, Hunan University of Science and Technology, Xiangtan 411201, People's Republic of China

${ }^{2}$ Key Laboratory of Environmental Biotechnology, Research Center

for Eco-Environmental Sciences, Chinese Academy of Sciences,

Beijing 100085, People's Republic of China

Full list of author information is available at the end of the article
}

soil (Cheraghi-Aliakbari et al. 2020). Cadmium (Cd), one of the most toxic heavy metals, and nonessential for humans and animals, is widely present in soil due to anthropogenic activities such as smelting, mining and battery disposal (DalCorso et al. 2019; Mitra et al. 2018). $\mathrm{Cd}$ accumulation in food could cause serious health problems in humans and animals (Khan et al. 2017). Phytoremediation is an efficient and environmental-friendly method to remove $\mathrm{Cd}$ from soil and could be used to remediate Cd pollution soil (Liu et al. 2020).

Under Cd stress, plants are damaged by photosynthesis inhibition and disruption of nutrition absorption ( $\mathrm{Li}$ et al. 2018), affecting the growth of sensitive plants (Wang et al. 2020a). However, Cd hyperaccumulators have 
higher tolerance to Cd, these include many types of Brassica species that can be grown under heavy metal stress in soil, with the whole plant being used for biofuel production (Rizwan et al. 2018). Brassica napus and Brassica juncea are widely grown around the world and have been investigated extensively for the remediation of Cd (Goswami and Das 2015; Rossi et al. 2002).

Soil is the main medium for terrestrial ecosystems, supporting productive activities, regulating nutrient flow, and maintaining ecosystem health with microbes playing a significant role in these processes (Xia et al. 2018). However, many studies have found that microbial diversity, abundance, and composition in soils are strongly affected by Cd contamination (Hou et al. 2018; Wood et al. 2016) As an essential part of ecosystems, microbial communities play an important role in global biogeochemical cycle (Beattie et al. 2018). Moreover, microorganisms are essential in biogeochemical cycling of HMs (Jing and Kjellerup 2018), with their responses to pollution having profound ecological effects and can serve as biological indicators of heavy metals such as Cd toxicity. Microorganisms are an important component of phytoremediation technology (Zhang et al. 2012). Phyllosphere (Jia et al. 2018) and endophytic bacteria (Wang et al. 2020b) are also beneficial in phytoremediation. However, less attention has been paid to the effect of $\mathrm{Cd}$ on plant microbial community (phyllospheric and endophytic bacterial communities) in the soil-plant ecosystem.

In this study, we chose two species of oilseed rapes ( $B$. napus and $B$. juncea) to investigate the effect of $\mathrm{Cd}$ on plants and compared their Cd-tolerance. A 16S rRNA gene amplicon Illumina Miseq approach was performed to examine effects of $\mathrm{Cd}$ contamination on bacterial communities in the soil-plant ecosystem. Our results provide a detailed understanding of the effects of $\mathrm{Cd}$ on plants and soil-plant system microbial communities and help improve phytoremediation systems.

\section{Material and methods}

\section{Greenhouse experiments}

The test soil was agricultural topsoil $(0-20 \mathrm{~cm})$ taken from a suburb of Hunan province $\left(27^{\circ} 54^{\prime} 15^{\prime \prime} \mathrm{N}\right.$, $\left.112^{\circ} 55^{\prime} 06^{\prime \prime} \mathrm{E}\right)$ and the main properties of the soil prior to any treatment were as follows: $\mathrm{pH} 5.56$, total organic carbon (TOC) 1.62\%, total nitrogen (TN) $1803.74 \mathrm{mg} /$ $\mathrm{kg}$, total phosphorus (TP) $921.04 \mathrm{mg} / \mathrm{kg}$, available phosphorus (AP) $78.14 \mathrm{mg} / \mathrm{kg}$, available potassium (AK) $135.41 \mathrm{mg} / \mathrm{kg}$, ammonia nitrogen $\left(\mathrm{NH}_{3}-\mathrm{N}\right) 17.65 \mathrm{mg} / \mathrm{kg}$ and nitrate nitrogen $\left(\mathrm{NO}_{3}-\mathrm{N}\right) 19.44 \mathrm{mg} / \mathrm{kg}$ and a background Cd concentration of $0 \mathrm{mg} / \mathrm{kg}$.

The B. napus L. cultivar "Zhong-shuang 11" and $B$. juncea L. cultivar "Purple Leaf Mustard" was used in this experiment. The plants were grown in a greenhouse located at the Hunan University of Science and Technology $\left(27^{\circ} 54^{\prime} 15^{\prime \prime} \mathrm{N}, 112^{\circ} 55^{\prime} 06^{\prime \prime} \mathrm{E}\right.$, Hunan, China) between October 11, 2018 and November 30, 2018. Soils were disposed by air-dried, ground and sieved by a $5 \mathrm{~mm}$ mesh. Then $\mathrm{Cd}$ aqueous solution $\left(\mathrm{CdCl}_{2} \cdot 2.5 \mathrm{H}_{2} \mathrm{O}\right)$ was carefully added into the soil to obtain three $\mathrm{Cd}$ concentrations (Control $(\mathrm{CK}), 0 \mathrm{mg} / \mathrm{kg} \mathrm{Cd}$; concentration 1 (C10), $10 \mathrm{mg} / \mathrm{kg} \mathrm{Cd}$; and concentration 2 (C30), $30 \mathrm{mg} /$ $\mathrm{kg}$ ) were applied. After mixing and being allowed to stabilize for three weeks, the soil $(7 \mathrm{~kg})$ was transferred into plastic pots ( $49 \mathrm{~cm}$ length $\times 14 \mathrm{~cm}$ wide $\times 20 \mathrm{~cm}$ high). Seeds were sown directly into pots and ten plants were maintained in each pot finally, they were planted in the greenhouse at $20^{\circ} \mathrm{C} \pm 10^{\circ} \mathrm{C}$ with suitable humidity. Every treatment was set to six replicates. Plant height and fresh weight were calculated manually and the total leaf area was measured using Image J software.

\section{Sample collection}

Soil samples were divided into two parts, one for measuring soil physico-chemical properties while the other for conducting molecular tests. Plant samples were obtained 50 days after planting, the aboveground and belowground parts were harvested dividually by sterile scissors. Microorganisms in the soil-plant ecosystems (including the rhizosphere, bulk soil, phyllospheric, and endophytic bacterial communities) were collected on the basis of Kong et al. (2018).

\section{Measure of $\mathrm{Cd}$ content in soil and plant tissues}

The samples were oven-dried, then ground and finally digested using $\mathrm{HNO}_{3}$ in a microwave (PyNN 140899, Peian, Beijing, China), and the contents of $\mathrm{Cd}$ were measured using flame atomic absorption spectrophotometer (Agilent 200 AA, Agilent Technology Co. LTD).

The Bioaccumulation Factor (BAF) and Translocation Factor (TF) of B. napus and B. juncea were calculated as follows:

$$
\begin{aligned}
& \mathrm{BAF}=\frac{\text { Content of } \mathrm{Cd} \text { in shoots or roots }(\mathrm{mg} / \mathrm{kg})}{\text { Content of } \mathrm{Cd} \text { in soil }(\mathrm{mg} / \mathrm{kg})}, \\
& \mathrm{TF}=\frac{\text { Content of } \mathrm{Cd} \text { in shoots }(\mathrm{mg} / \mathrm{kg})}{\text { Content of } \mathrm{Cd} \text { in roots }(\mathrm{mg} / \mathrm{kg})} .
\end{aligned}
$$

\section{Physiological index of plant tissues}

The content of soluble sugar was determined by the anthrone colorimetry method (Dubois et al. 1956), using the assay kit provided by Nanjing Jiangcheng Bioengineering Institute. According to Li et al. (2013), the homogenate was collected for antioxidant enzyme activity measurement with some modifications. Commercially 
available assay kits (Nanjing Jiangcheng Bioengineering Institute) were used to determine the activities of superoxide dismutase (SOD, hydroxylamine method), catalase (CAT, visible light method), and peroxidase (POD, colorimetric method) according to the manufacturer's instructions. The content of soluble protein and chlorophyll in leaf samples was measured by the Coomassie Brilliant Blue G250 staining method (Bradford 1976) and acetone extraction method (Kim et al. 2017), respectively.

\section{Physicochemical property of soils}

Soil $\mathrm{pH}$ and the content of TN, TP, TOC, $\mathrm{NH}_{3}-\mathrm{N}$, $\mathrm{NO}_{3}-\mathrm{N}, \mathrm{AP}$ and $\mathrm{AK}$ were measured according to Kong et al. (2018).

\section{DNA extraction, PCR amplification, and sequencing}

A total of 180 samples (divided equally into five parts including phyllosphere, leaf endophyte, root endophyte, rhizosphere soil and bulk soil samples) were sequenced by the following steps. DNA was extracted using Fast DNA spin kit for soil (MP Biomedicals LLC, USA). Primer 799F (5'-AACMGGATTAGATACCCKG-3'), which excludes contamination from chloroplast DNA (Beckers et al. 2016; Ghyselinck et al. 2013) and a primer designed for this study, 1115R (5'-AGGGTTGCGCTC GTTG-3'), were used to amplify V5-V6 region of the $16 \mathrm{~S}$ rRNA gene.

The PCR reaction system $(50 \mu \mathrm{L}): 37.5 \mu \mathrm{l}$ of $\mathrm{ddH}_{2} \mathrm{O}$, $5 \mu \mathrm{L}$ of $10 \times$ PCR buffer, $4 \mu \mathrm{L}$ of $2.5 \mathrm{mmol} / \mathrm{L}$ dNTPs, $0.5 \mu \mathrm{L}$ of $5 \mathrm{U} / \mu \mathrm{L}$ Taq DNA polymerase (TaKaRa Biotech, Beijing, China), $1 \mu \mathrm{L}$ of $10 \mu \mathrm{mol} / \mathrm{L}$ forward and reverse primers and $1 \mu \mathrm{L}$ of the DNA template $(20-30 \mathrm{ng} / \mu \mathrm{L})$. Cycling conditions were set as follows: $94{ }^{\circ} \mathrm{C}$ for $1 \mathrm{~min}$, followed by 30 cycles of $94{ }^{\circ} \mathrm{C}$ for $20 \mathrm{~s}, 57^{\circ} \mathrm{C}$ for $25 \mathrm{~s}$, $72{ }^{\circ} \mathrm{C}$ for $45 \mathrm{~s}$, then a final extension cycle at $72{ }^{\circ} \mathrm{C}$ for $10 \mathrm{~min}$. PCR products were recovered by agarose gel electrophoresis and purified using E.Z.N.A. TM Gel Extraction Kit (Omega Biotek, Norcross, GA, USA). The purified PCR products were quantified by Nanodrop Spectrophotometer (ND-2000 Spectrophotometer, Wilmington, DE, USA). Each PCR purified product $(150 \mathrm{ng})$ was mixed to construct the sequencing library. The samples were sequenced by Illumina Miseq platform at BeiJing Fixgene Co., Ltd.

\section{Quantitative PCR}

For determining abundances of bacteria, Quantitative PCR (qPCR) was performed by using the primer pair 799F (5'-AACMGGATTAGATACCCKG-3') and 1115R (5'-AG GGTTGCGCTCGTTG-3') together with a CFX Connect TM Real-Time PCR Detection System (Bio$\mathrm{Rad})$. The qPCR reaction mixture which used MonAmp ${ }^{\text {TM }}$ SYBR $^{\circledR}$ qPCR Mix (Monad Biotech Co., Ltd) was done in a volume of $20 \mu \mathrm{l}$ consisting of $10 \mu \mathrm{L}$ of qPCR Mix, $1 \mu \mathrm{L}$ of each primer, $1 \mu \mathrm{L}$ of template DNA and $7 \mu \mathrm{L}$ of nuclease-free water. qPCR procedure was set as follows: $95^{\circ} \mathrm{C}$ for $30 \mathrm{~s}, 40$ cycles of $95^{\circ} \mathrm{C}$ for $5 \mathrm{~s}, 57^{\circ} \mathrm{C}$ for $10 \mathrm{~s}, 72^{\circ} \mathrm{C}$ for $30 \mathrm{~s}$. Every sample was amplified in triplicate.

\section{Sequencing data process}

Processing of the raw sequencing data was performed on a Galaxy pipeline (http://mem.rcees.ac.cn:8080) at Research Center for Eco-Environmental Science, China Academy of Sciences. The procedures were as follows: raw reads were assigned to different samples using barcodes, followed by removal of primers sequences, forward and reverse sequences were combined by FLASH (Magoč and Salzberg 2011), and sequences shorter than 200 bp were removed using Btrim (Kong 2011). Extraction of FASTA data from FASTQ data, checking for and removal of chimeras, and assignment of sequences with 97\% identity to the same operational taxonomic unit (OTU) were performed using the UPARSE algorithm (Edgar 2013). The RDP Classifier database was used to Taxonomic assignment (Wang et al. 2007). In order to avoid the effects caused by different sequencing depth, the data was resampled randomly with the minimum number of sequences $(30,000)$. The following analysis used the resampled OTU table.

The raw reads generated in this study have been deposited in the NCBI sequence Read Archive (Accession No. SRP283176).

\section{Statistical analysis}

The relative abundance of top 10 phyla and top 50 genera were selected in line with the results of phyllospheric, leaf and root endophytic, rhizosphere and bulk soil bacterial communities species annotations respectively. One-way ANOVA method was conducted to analyze the significance difference $(P<0.05)$ between treatments. The relationship between environmental factors and $\alpha$-diversities was investigated by pearson's correlation analysis. ANOVA method and Pearson's correlation test were performed using SPSS 21 software. The dissimilarity test was performed to evaluate the significance of clustering. Weighted principal coordinate analysis (PCoA) on the UniFrac matrix was applied to compare the different samples' bacterial community structure. Mantel test, canonical correspondence analysis (CCA) was used to show which environmental factors significantly impact microbial community structure and CCA-based variation partitioning analysis (VPA) was used to determine the contributions of Environmental Factors (EFs) to bacterial community. 


\section{Results}

\section{Effect of Cd on physiological properties of oilseed rapes} and $\mathrm{Cd}$ accumulation

Compared to the control (CK), Cd treatment suppressed plant growth (Fig. 1), specifically plant height, fresh weight, and total leaf area were significantly reduced with increasing $\mathrm{Cd}$ concentration $(P<0.05)$. At $\mathrm{CK}$ and lower $\mathrm{Cd}$ concentration $(10 \mathrm{mg} / \mathrm{kg})$, the biomass of $B$. napus was significantly higher than $B$. juncea, but at higher $\mathrm{Cd}$ concentration $(30 \mathrm{mg} / \mathrm{kg}$ ) those tendencies were reversed. Pearson correlation analysis showed that Cd content in tissues was negatively correlated with plant height, weight, and leaf area in $B$. napus and $B$. juncea $(P<0.01)$ (Additional file 1: Table S1, S2).

Chlorophyll was significantly decreased under higher Cd concentration, with $B$. juncea being significantly less affected than $B$. napus $(P<0.05)$ (Fig. 1D). Soluble sugar content was markedly decreased under $\mathrm{Cd}$ stress in both of $B$. napus and B. juncea, while the content of soluble protein was markedly increased under $\mathrm{Cd}$ treatment when compared with $\mathrm{CK}(P<0.05)$ (Fig. 1E, F). SOD and POD activity values showed similar trends, decreasing at first and then increasing. The SOD activity at $30 \mathrm{mg} /$ $\mathrm{kg}$ was significantly higher than in other treatments $(P<0.05)$. However, CAT activity was notably inhibited at the higher $\mathrm{Cd}$ concentration $(P<0.05)$. SOD and POD activity were higher in $B$. napus than $B$. juncea, while CAT activity values were the reverse (Fig. 1G-I). Pearson correlation test showed that plant $\mathrm{Cd}$ content was negatively related with chlorophyll, soluble sugar, and CAT activity $(P<0.01)$ and positively related with soluble protein and SOD activity $(P<0.05)$ in $B$. napus and $B$. juncea (Additional file 1: Table S1, S2).

The concentration of $\mathrm{Cd}$ in oilseed rape leaves and roots were significantly higher with increasing $\mathrm{Cd} \mathrm{lev-}$ els, and $\mathrm{Cd}$ content in $B$. napus tissues was significantly higher than $B$. juncea $(P<0.05)$ (Additional file 1: Figure $\mathrm{S} 1)$. Translocation Factor (TF) in the two oilseed rapes

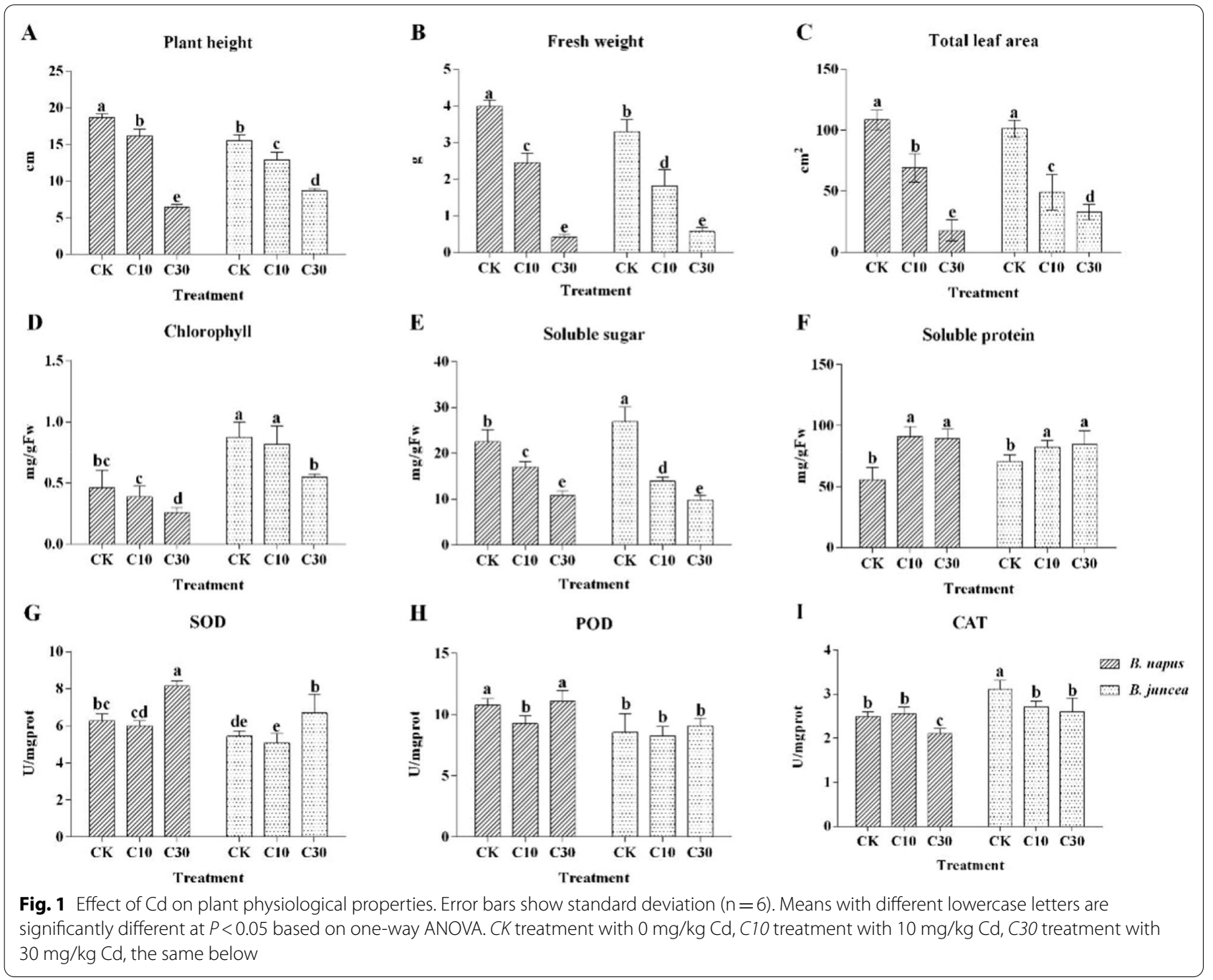


species significantly decreased with increasing $\mathrm{Cd}$ and was higher in $B$. napus than $B$. juncea $(P<0.05)$ (Additional file 1: Table S3). Bioaccumulation Factor (BAF) in leaves and roots of both $B$. napus and $B$. juncea was bigger than one and higher in C30 $(30 \mathrm{mg} / \mathrm{kg})$ treatment compared to $\mathrm{C} 10(10 \mathrm{mg} / \mathrm{kg})$ treatment, especially in roots (Additional file 1: Table S3).

\section{Effect of $\mathrm{Cd}$ on physicochemical properties of soils}

In $B$. napus, the $\mathrm{pH}, \mathrm{TN}, \mathrm{TP}$, and $\mathrm{NO}_{3}-\mathrm{N}$ were significantly decreased under the higher $\mathrm{Cd}$ concentration $(P<0.05)$ and TOC first increased and then decreased in both rhizosphere and bulk soils (Fig. 2), meanwhile TOC, $\mathrm{TN}, \mathrm{NH}_{3}-\mathrm{N}$, and AP were higher, and $\mathrm{pH}$ lower, in rhizosphere than bulk soil. $\mathrm{pH}$ and $\mathrm{TN}$ were markedly reduced in the $30 \mathrm{mg} / \mathrm{kg} C \mathrm{~d}$ treatment $(P<0.05)$ and $\mathrm{NH}_{3}-\mathrm{N}$ was first increased and then decreased in both rhizosphere and bulk soils, while AK was significantly increased $(P<0.05)$ in bulk soil of $B$. juncea under the higher $\mathrm{Cd}$ concentration (Fig. 2). Furthermore, TOC, TN, TP, $\mathrm{NH}_{3}-\mathrm{N}, \mathrm{NO}_{3}-\mathrm{N}$, and $\mathrm{AK}$ were higher, and $\mathrm{pH}$ was lower in rhizosphere than bulk soil in B. juncea. Compared with $B$. napus, most soil nutrients were higher in $B$. juncea samples under the higher $\mathrm{Cd}$ treatment.

Pearson correlation analysis showed that for $B$. napus, the $\mathrm{Cd}$ content was negatively correlated with $\mathrm{pH}, \mathrm{TN}$, $\mathrm{TP}$, and $\mathrm{NO}_{3}-\mathrm{N}$ content in both rhizosphere and bulk soils and with TOC of the rhizosphere (Additional file 1:

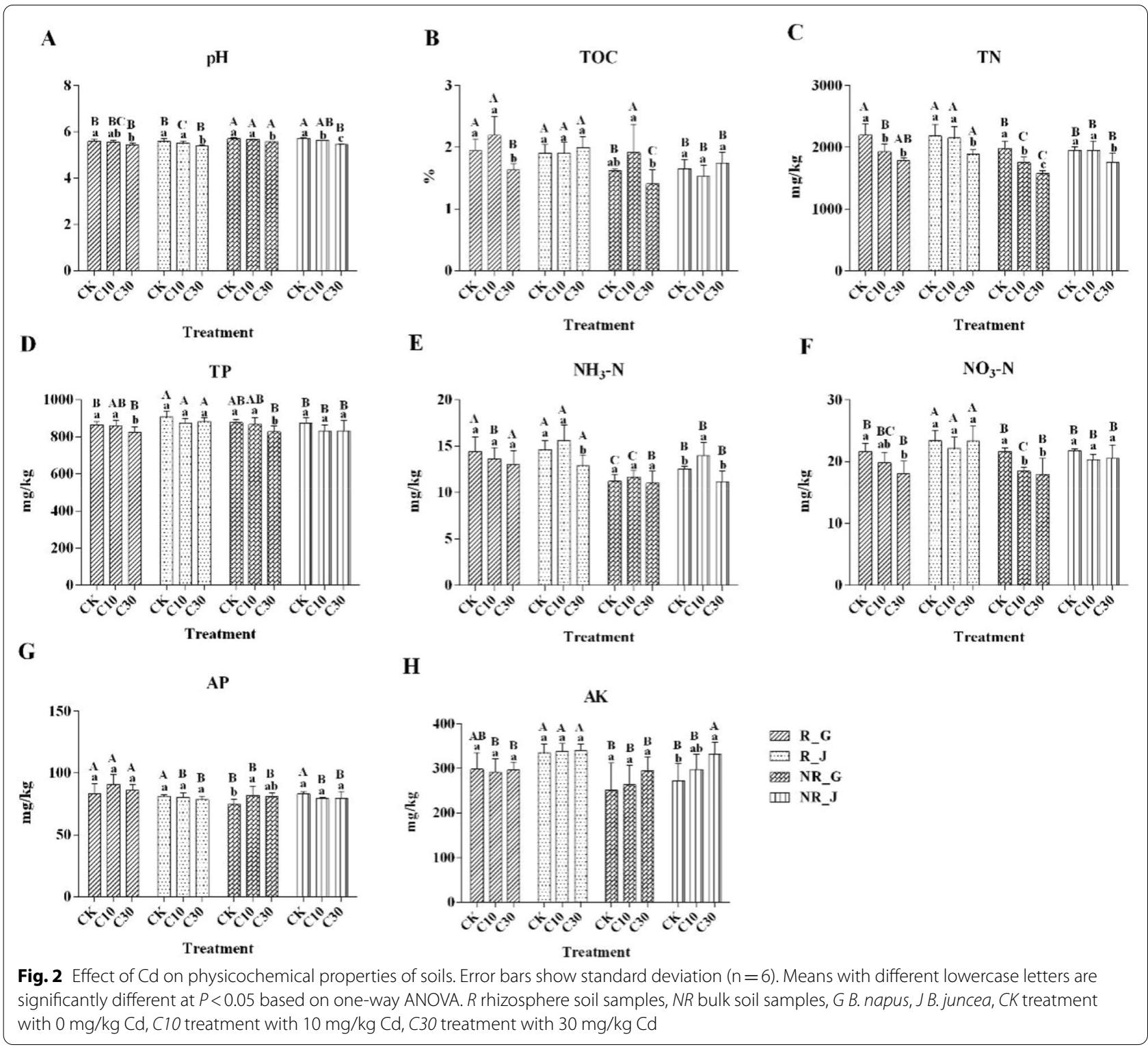


Table S4, S6). Cd was negatively correlated with $\mathrm{pH}, \mathrm{TN}$, and $\mathrm{NH}_{3}-\mathrm{N}$ content in rhizosphere and bulk soils and negatively correlated with AP of the rhizosphere, but positively correlated with AK of bulk soil in B. juncea $(P<0.05)$ (Additional file 1: Table S5, S7).

\section{Effect of $\mathrm{Cd}$ on bacterial numbers in soils}

The results revealed that there are not significantly change of total bacterial numbers between treatment in rhizosphere, but bacterial numbers in bulk soil of $B$. napus was significantly increased under $\mathrm{Cd}$ stress $(P<0.05)$ (Additional file 1: Figure S2). Pearson analysis showed that $\mathrm{Cd}$ was positively correlation with bacterial numbers in bulk soil of $B$. napus (Additional file 1: Table S8). Meanwhile, no significant difference was observed between B. napus and B. juncea $(P>0.05)$.

\section{Effect of $\mathrm{Cd}$ on the a-diversity of bacterial community}

After removing low quality reads and chimaeras in 108 plant samples and 72 soil samples, a total of 13,352,813 high-quality $16 \mathrm{~S}$ rRNA gene reads were obtained, which were clustered into 14,359 phylotypes (OTUs) by grouping at a $97 \%$ identity threshold. The sequencing depths of all samples were appropriate for downstream analyses (Additional file 1: Figure S3).

In the plant samples, $\mathrm{Cd}$ mainly affected root endophytic community of $B$. napus and phyllosphere community of $B$. juncea. Shannon index and richness of $B$. napus's root endophytes and the richness and Chaol of B. juncea's phyllosphere decreased significantly at the higher $\mathrm{Cd}$ concentration $(P<0.05)$ (Additional file 1 : Figure S4). Pearson correlation analysis demonstrated that plant physiological factors mainly correlated with $\alpha$-diversity indexes of root endophytes in $B$. napus (Additional file 1: Table S10) and that the majority of plant physiological properties were cardinally correlated with OTU numbers (richness and Chao1) of phyllosphere in B. juncea (Additional file 1: Table S11). $\mathrm{pH}$ and TOC were significantly positive correlated with and $\mathrm{Cd}$ was significantly negative correlated with the $\alpha$-diversity of root endophytic bacterial communities in B. napus (Additional file 1: Table S10).

However, high level of Cd significantly depressed the $\alpha$-diversities in the soil bacterial communities. Simpson index of rhizosphere and bulk soil was markedly reduced in the $30 \mathrm{mg} / \mathrm{kg} \mathrm{Cd}$ treatment in $B$. napus $(P<0.05)$ (Fig. 3). Shannon and Simpson indexes of rhizosphere and Shannon, Simpson, richness and Chaol of bulk soils in $B$. juncea were significantly decreased under the higher $\mathrm{Cd}$ treatment $(P<0.05)$ (Fig. 3$)$. Most $\alpha$-diversity indexes between the two species of oilseed rapes had no significant differences.

Pearson tests showed that plant's physiological factors mainly influenced $\alpha$-diversity indexes of the rhizosphere in B. napus and bacterial diversity (Shannon and Simpson indexes) of the rhizosphere in B. juncea (Additional file 1: Table S12, S13). pH, TOC, TN, TP, and $\mathrm{NO}_{3}-\mathrm{N}$ were positively correlated with the $\alpha$-diversity in rhizosphere of B. napus. Meanwhile, $\mathrm{TN}$ and $\mathrm{NO}_{3}-\mathrm{N}$ were positively correlated with bacterial diversity (Shannon and

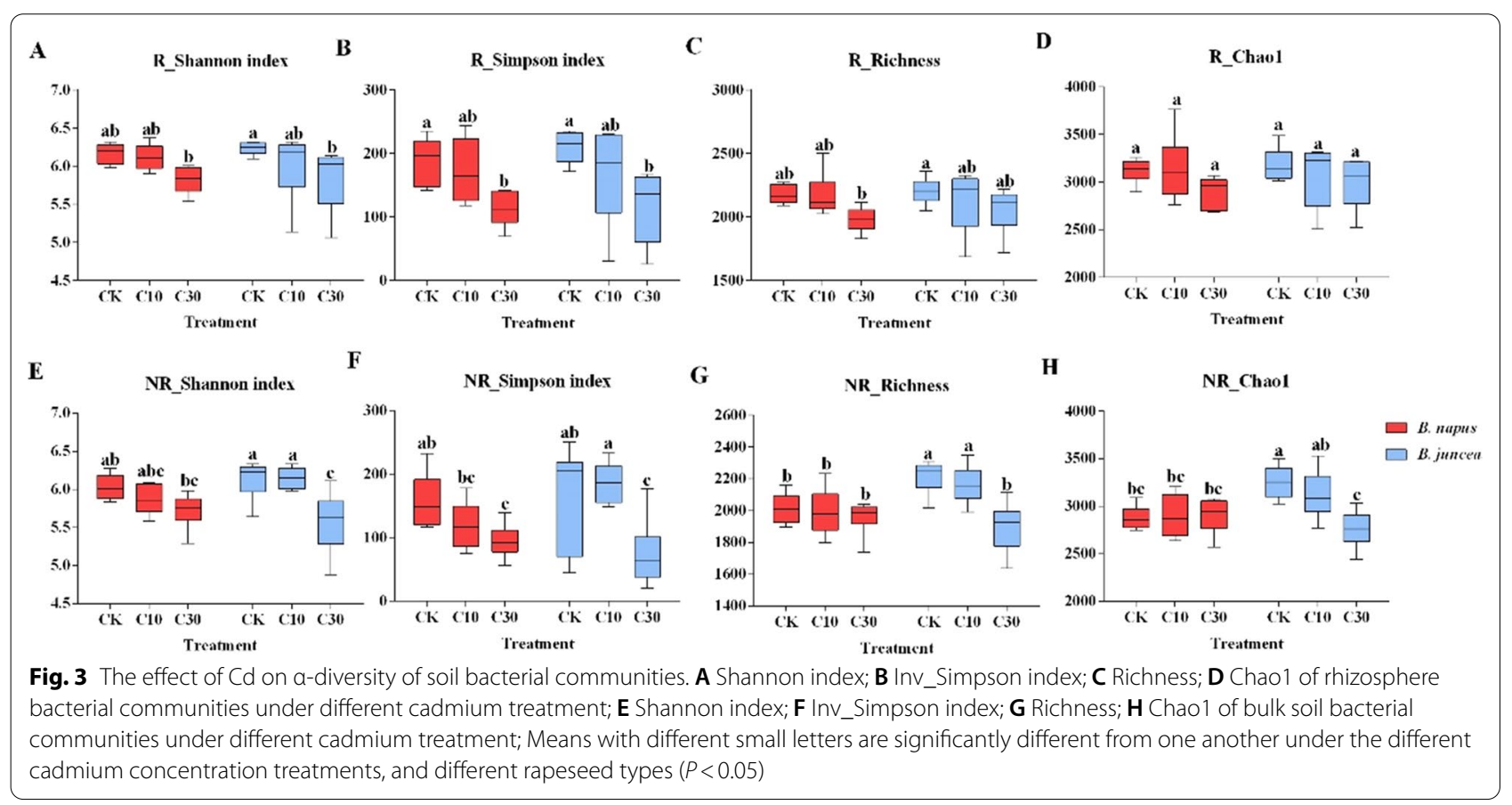


Simpson indexes) of bulk soil in B. napus samples (Additional file 1: Table S12). In B. juncea, $\mathrm{pH}$ was positively, and AK negatively, correlated with $\alpha$-diversity in bulk soil (Additional file 1: Table S13). However, Cd concentration showed a significant negative correlation with $\alpha$-diversity of soil bacteria communities for both species of oilseed rapes $(P<0.05)$ (Additional file 1: Table S12, S13).

\section{Effect of $\mathrm{Cd}$ on bacterial community composition and structure}

Cd could affect the composition of bacterial communities in soil-plant ecosystem, particularly under higher levels of $\mathrm{Cd}$ stress. In the plant bacterial community, Proteobacteria was dominant phylum (Additional file 1: Figure S5A). Under Cd treatment, the relative abundance of Proteobacteria was decreased in the B. napus phyllosphere, and decreased at first and then increased in the $B$. napus endophyte. However, in the B. juncea, the relative abundance of Proteobacteria of phyllosphere and root endophyte was increased and was decreased in leaf endophyte. In the soil bacterial community, Proteobacteria and Actinobacteria were dominant phyla (Additional file 1: Figure S5B). The relative abundance of Proteobacteria of soil bacterial community was increased under $\mathrm{Cd}$ stress. The relative abundance of Actinobacteria was decreased under higher $\mathrm{Cd}$ stress in the B. napus and was increased in the B. juncea under $\mathrm{Cd}$ treatment.
At the genus level (Fig. 4), the relative abundance of some genera was altered under $\mathrm{Cd}$ treatment. In the $B$. napus phyllosphere samples, the relative abundances of Massililia sp., Rhodanobacter sp., and Rickettsia sp. were increased, and Buchera sp., Achromobacter sp., and Acinetobacter sp. were decreased under Cd treatment. While in B. juncea phyllosphere samples, Lysobacter sp., Stenotrophomonas sp., and Gibbsiella sp. were increased, while Gaiell sp., Telluria sp., and Herbaspirillum sp. were decreased under $\mathrm{Cd}$ treatment. In leaf endophyte samples, Brochothrix sp. and Acinetobacter sp. were increased in B. napus but decreased in B. juncea under $\mathrm{Cd}$ treatment. In root endophyte samples, Chryseobacterium sp. and Pantoea sp. were increased and Caulobacter Ideonella sp. and Herbaspirillum sp. were decreased in B. napus. Sphingomonas sp., Ralstonia sp., and Methylobacterium sp. were increased, and Rhizobium sp., Rhodanobacter sp., and Duganella sp. were decreased in B. juncea under $\mathrm{Cd}$ treatment.

In the rhizosphere, Niastella sp., Methylotenera sp., and Lystobacter sp. were increased and Arthrobacter sp., Gemmatimanas sp., and Haliangium sp. were decreased in B. napus under $30 \mathrm{mg} / \mathrm{kg} \mathrm{Cd}$ treatment. Massilia sp., Ralstonia sp., and Streptomyces sp. were increased and GP2 sp., Terriglobus sp., and Candidatus Solibacter sp. were decreased in B. juncea under $30 \mathrm{mg} / \mathrm{kg} C \mathrm{Cd}$ treatment. In bulk soil, Sphingomonas sp., Rhodanobacter sp., and Roseateles sp. were increased and Arthrobacter sp.,

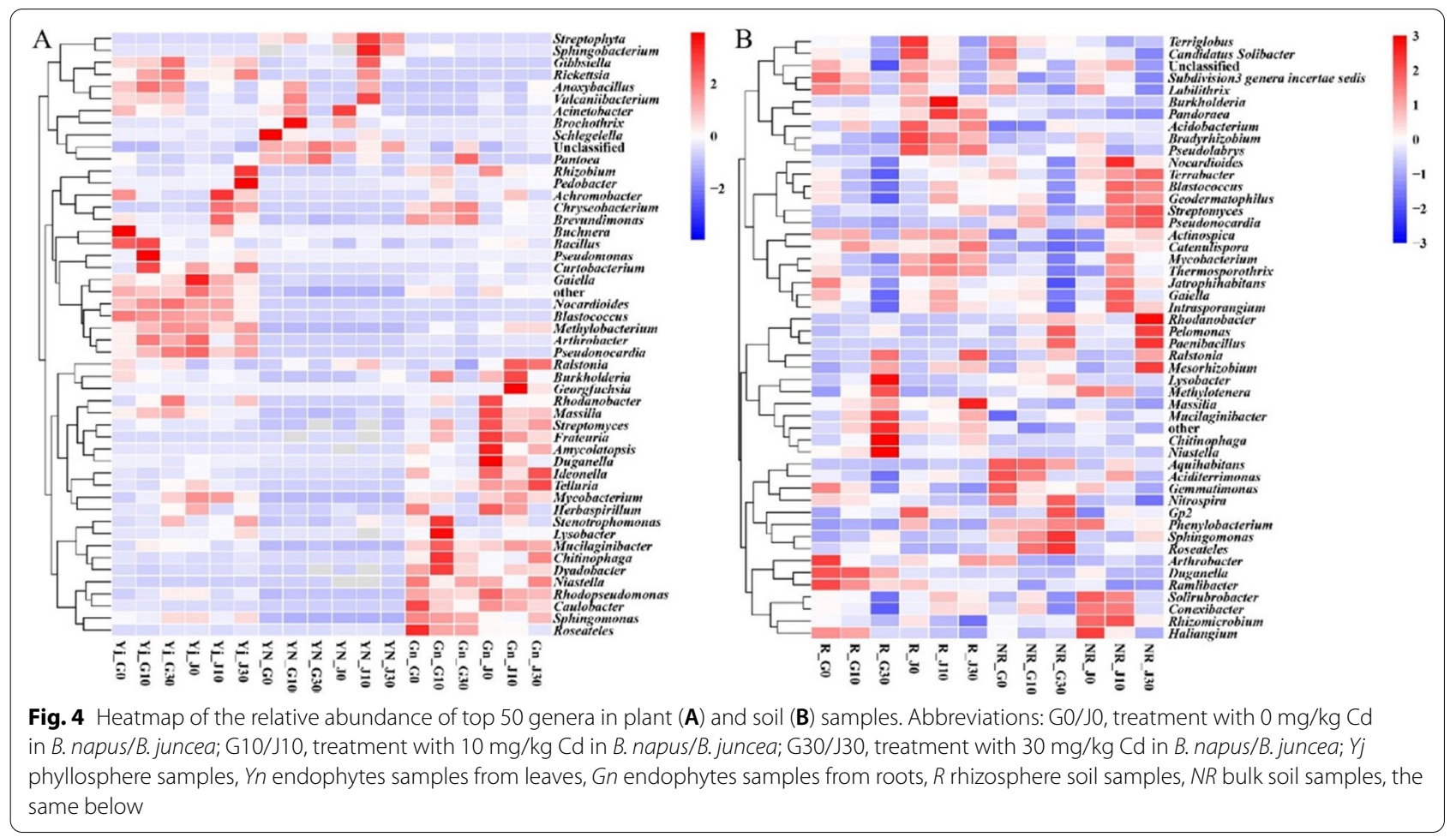


Gemmatimonas sp., and Terriglobus sp. were decreased in B. napus. Streptomyces sp., Pseudomocardia sp., and Blastococcus sp. were increased and Haliangium sp., Phenylobacterium ap., and Gemmatimonas sp. were decreased in B. juncea under Cd treatment.

The principal co-ordinates analysis (PCoA) (Fig. 5) and dissimilarity analysis (Additional file 1: Table S14, S15) indicated that the bacterial community structures of both rhizosphere and bulk soil in both $B$. napus and B. juncea were significantly changed under higher $C d$ concentration compared to control $(P<0.05)$, but not significantly affected plant bacterial community structures.

\section{Relationship between microbial community structure and environmental factors}

The result of Mantel test showed that there are no significant association between most environment factors and phyllosphere or leaf endophyte bacterial communities (Additional file 1: Table S16, S17). Biomass (height, weight, and leaf area), TOC and root $\mathrm{Cd}$ had significant association with root endophyte bacterial community in B. napus (Additional file 1: Table S16). Biomass, $\mathrm{pH}$, $\mathrm{NO}_{3}-\mathrm{N}$ and Soil_Cd had significant association with rhizosphere bacterial communities and TN and Soil_Cd had significant association with bulk soil bacterial communities in B. napus (Table 1). Biomass, TN and Soil_Cd were significant correlated with rhizosphere bacterial community in B. juncea and $\mathrm{pH}$ and Soil_Cd were significant correlated with bulk soil bacterial community in $B$. juncea (Additional file 1: Table S18).

The CCA model of root endophyte, rhizosphere and bulk soil bacterial community were significant $(P<0.05$, Additional file 1: Figure S6A, S7A and Fig. 6A). The results of VPA indicated that biomass, $\mathrm{pH}$, soil nutrients,
Table 1 Mantel analysis of the relationship between the soil bacterial community structure in B. napus and environmental factors based on Bray Curtis (BC) and Jaccard (JC) method

\begin{tabular}{|c|c|c|c|c|c|}
\hline Samples & $\begin{array}{l}\text { Environmental } \\
\text { factors }\end{array}$ & $r . \mathrm{BC}$ & $p . \mathrm{BC}$ & r.JC & p.JC \\
\hline \multirow[t]{12}{*}{ Rhizosphere soil } & Height & 0.6394 & 0.001 & 0.3089 & 0.001 \\
\hline & Weight & 0.5874 & 0.001 & 0.2704 & 0.001 \\
\hline & Leaf_area & 0.5709 & 0.001 & 0.2964 & 0.001 \\
\hline & $\mathrm{pH}$ & 0.2294 & 0.031 & 0.0347 & 0.348 \\
\hline & TOC & 0.1250 & 0.192 & 0.0323 & 0.336 \\
\hline & $\mathrm{TN}$ & 0.1993 & 0.056 & 0.0037 & 0.421 \\
\hline & $\mathrm{TP}$ & 0.0518 & 0.293 & -0.0074 & 0.475 \\
\hline & $\mathrm{NH}_{3}-\mathrm{N}$ & 0.1902 & 0.075 & -0.0443 & 0.567 \\
\hline & $\mathrm{NO}_{3}-\mathrm{N}$ & 0.2159 & 0.028 & -0.0811 & 0.711 \\
\hline & $\mathrm{AP}$ & -0.1334 & 0.899 & 0.2172 & 0.081 \\
\hline & AK & -0.0977 & 0.777 & -0.1445 & 0.804 \\
\hline & Soil_Cd & 0.6319 & 0.001 & 0.3198 & 0.003 \\
\hline \multirow[t]{9}{*}{ Bulk soil } & $\mathrm{pH}$ & 0.1710 & 0.092 & 0.0154 & 0.412 \\
\hline & TOC & 0.0624 & 0.361 & 0.0554 & 0.326 \\
\hline & TN & 0.2064 & 0.035 & 0.1129 & 0.158 \\
\hline & $\mathrm{TP}$ & -0.0074 & 0.507 & -0.0625 & 0.631 \\
\hline & $\mathrm{NH}_{3}-\mathrm{N}$ & -0.1643 & 0.886 & -0.0580 & 0.608 \\
\hline & $\mathrm{NO}_{3}-\mathrm{N}$ & 0.0963 & 0.143 & 0.0007 & 0.482 \\
\hline & $\mathrm{AP}$ & 0.1708 & 0.14 & -0.0058 & 0.481 \\
\hline & AK & 0.1677 & 0.108 & -0.0081 & 0.481 \\
\hline & Soil_Cd & 0.2343 & 0.018 & 0.0764 & 0.243 \\
\hline
\end{tabular}

and Root_Cd explained 14.3\%, 5.4\%, 37.4\%, and 7.2\% of variation in B. napus (Additional file 1: Figure S6B) and $15.5 \%, 6.9 \%, 40.2 \%$, and $4.2 \%$ of variation in B. juncea (Additional file 1: Figure $\mathrm{S6C}$ ) in root endophyte bacterial community, respectively.
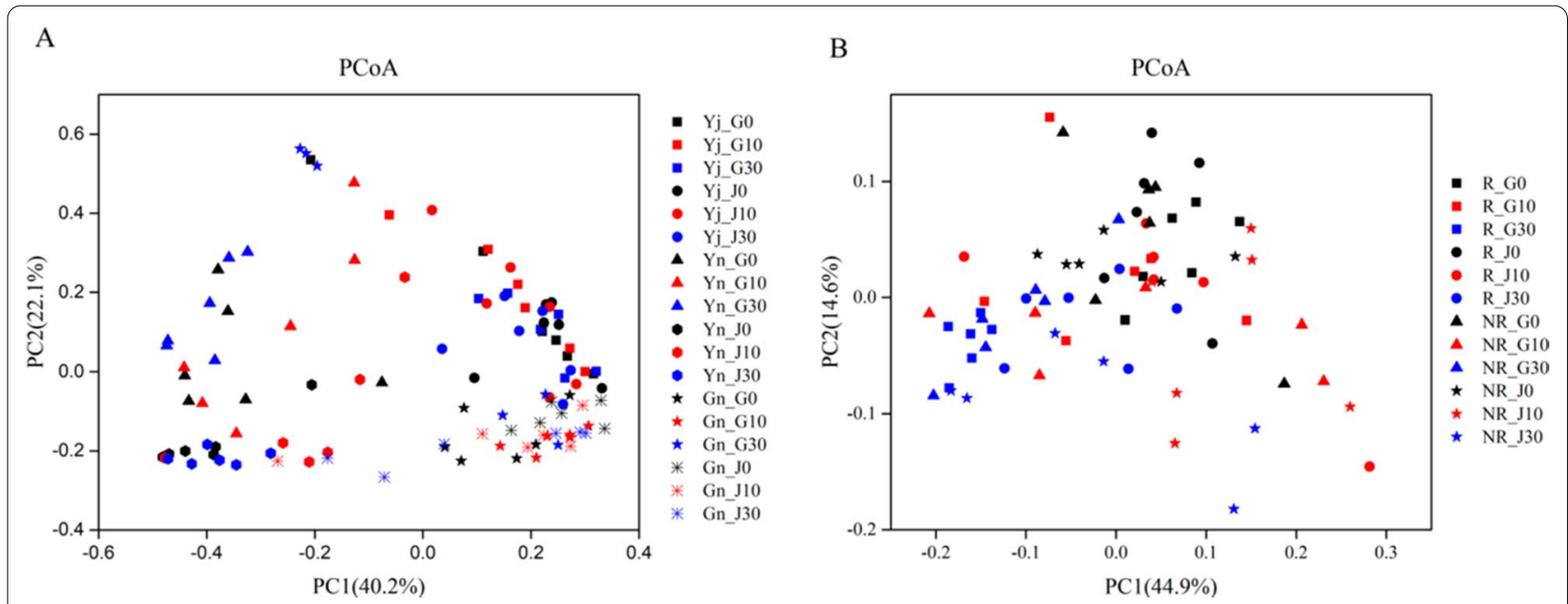

Fig. 5 Principal coordinate analysis (PCOA) of bacteria communities in plants (A) and soils (B) 
A
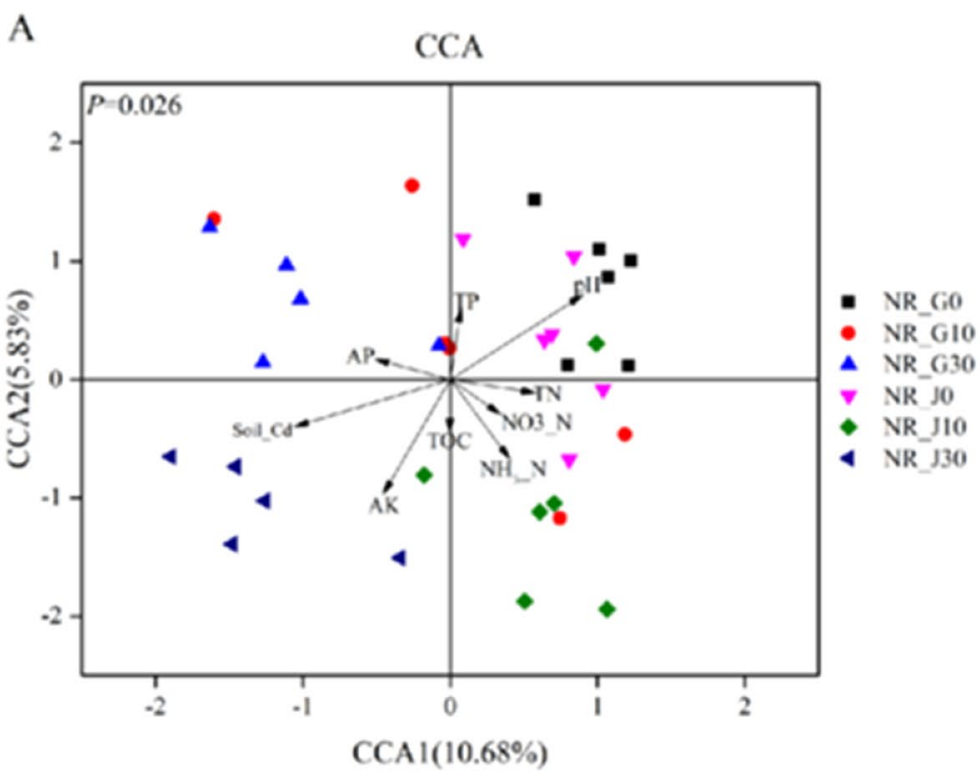

B

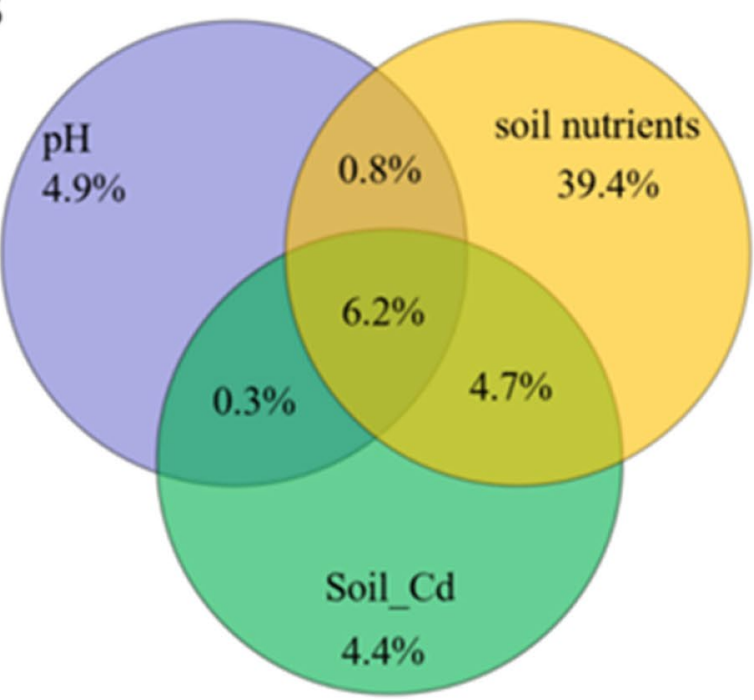

Unexplained:39.4\%

Bulk soil in B.napus
C

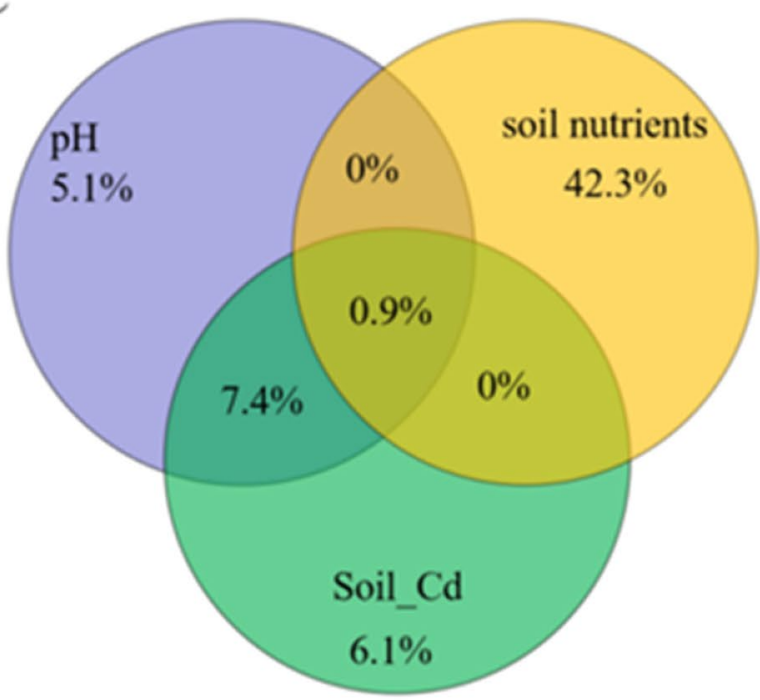

Unexplained:38.2\%

Bulk soil in B.juncea

Fig. 6 Canonical correspondence analysis (CCA) on bulk soil bacterial communities with the environmental variables (A) and CCA-based variation partitioning analysis (VPA) of bacterial communities explained by environmental variables (B, C)

CCA-based VPA indicated that biomass, $\mathrm{pH}$, soil nutrients, and $\mathrm{Cd}$ concentration of rhizosphere soil bacterial community explained $13.8 \%, 4.7 \%, 32.6 \%$, and $3.6 \%$ of variation in B. napus (Additional file 1: Figure $\mathrm{S} 7 \mathrm{~B}$ ), and $14.7 \%, 3.4 \%, 35.7 \%$, and $5.3 \%$ of variation in
B. juncea (Additional file 1: Figure S7C), respectively. For bulk soil bacterial community, VPA indicated that $\mathrm{pH}$, soil nutrients, and $\mathrm{Cd}$ explained $4.9 \%, 39.4 \%$, and $4.4 \%$ variation in B. napus (Fig. $6 \mathrm{~B}$ ) and $5.1 \%, 42.3 \%$, and $6.1 \%$ variation in $B$. juncea (Fig. $6 \mathrm{C}$ ), respectively. 


\section{Discussion}

In this research, we comprehensively studied the effect of $\mathrm{Cd}$ contamination on soil-plant system by comparing the variance of bacterial community under different $\mathrm{Cd}$ treatments. The results reflected that $\mathrm{Cd}$ could inhibit the growth of both species of oilseed rapes, and change the bacterial community structure in soil-plant ecosystem, especially in soil.

Cd could be accumulated in plants from soil via root absorption (Khan, et al. 2017). In the current study, Cd content in B. napus and B. juncea tissues both increased with increasing $\mathrm{Cd}$ levels (Additional file 1: Figure S1). Hyperaccumulators generally have BAF values higher than 1 (Gascó et al. 2019). The results revealed that BAF in both $B$. napus and B. juncea, leaves and roots, were higher than 1 indicating that they are accumulator plants (shoots and roots) for Cd (Additional file 1: Table S3). TF in two oilseed rapes species was significantly decreased with elevated levels of $\mathrm{Cd}$, which indicated the translocation capability of rapeseeds decreased under higher $\mathrm{Cd}$ treatment (Additional file 1: Table S3). Zeng et al. (2020) also found that TF values were decreased when the $\mathrm{Cd}$ concentration was elevated. It should be noted that $\mathrm{Cd}$ accumulation in tissues and TF values in B. napus were significantly higher than B. juncea. It may be due to different adsorption coefficients of $\mathrm{Cd}$ by different plant (Rattan et al. 2005).

Additionally, the accumulation of $\mathrm{Cd}$ in plants could also cause plant growth inhibition (Fig. 1). The biomass was declined with increasing $\mathrm{Cd}$ levels. This inhibition might be due to $\mathrm{Cd}$ inhibiting photosynthesis, retarding plant growth, since the content of chlorophyll decreased with increasing $\mathrm{Cd}$ concentration (Fig. 1D). One recent report demonstrated that total chlorophyll concentrations decreased with increasing $\mathrm{Cd}$ concentrations, which was accompanied by the reduction of biomass (Liu et al. 2011). However, in comparison between the two species of oilseed rapes, biomass of $B$. juncea was markedly higher than $B$. napus under the higher $\mathrm{Cd}$ concentration $(30 \mathrm{mg} / \mathrm{kg})$ while $B$. napus was significantly higher than $B$. juncea under CK treatment. The result indicated that $B$. juncea might have stronger $C d$ resistance than $B$. napus.

When plants experience Cd stress, antioxidative enzymes are induced (Belimov et al. 2007). In the current study, SOD and POD activities were elevated under the higher $\mathrm{Cd}$ concentration compared with $\mathrm{CK}$, especially for SOD activity (Fig. 1G), while CAT activity was opposite (Fig. 1I). SOD is the first line to defend against ROS, so its activity increasing means that ROS production was enhanced. Increases in SOD activity could enhance $\mathrm{H}_{2} \mathrm{O}_{2}$ production, which is accompanying with an inhibition of CAT activity (Giansoldati et al. 2012). In this study, SOD and POD activities were higher and CAT activity was lower in B. napus than B. juncea, which indicates Cd may cause more damage to cells in $B$. napus.

The above results revealed that $B$. juncea may have relatively higher $\mathrm{Cd}$-tolerance than $B$. napus. Molnár et al. (2020) found that higher levels of zinc oxide nanoparticles ( $\mathrm{ZnO} \mathrm{NPs}$ ) were toxic to oilseed rapes and B. juncea has higher tolerance to $\mathrm{ZnO}$ NPs than $B$. napus. This may be due to the higher chlorophyll content of $B$. juncea under all treatments (Fig. 1D).

$\mathrm{Cd}$, which is extensively found in agricultural soils (Guo et al. 2017), might interfere with the metabolic activity of local resident microorganisms, resulting in modified soil conditions (Lu et al. 2013). In this study, a portion of soil physiochemical properties was altered under $30 \mathrm{mg} /$ $\mathrm{kg}$ Cd contamination (Fig. 2). The result showed that $\mathrm{pH}$ was lower with the increase of $\mathrm{Cd}$ levels and it might be closely correlated with microbial activity (Deng et al. 2018). Nitrogen is an essential nutrient for all life forms and could limit the primary productivity in many ecosystems (Frey et al. 2004). Several types of nitrogen content $\left(\mathrm{NH}_{3}-\mathrm{N}, \mathrm{NO}_{3}-\mathrm{N}\right.$, and $\left.\mathrm{TN}\right)$ were significantly decreased under higher $\mathrm{Cd}$ concentration (30 mg/kg) (Fig. 2), indicating that $\mathrm{Cd}$ may detrimentally influence soil quality, possibly be due to a detrimental effect of the heavy metal on the nitrogen cycle. Work by Sarria Carabalí et al. (2020) showed that Cd contamination has serious effects on nitrogen mobilization.

The soil microorganism plays a role in soil ecosystem functions (Schulz et al. 2013). The $\alpha$-diversity of soil bacterial communities decreased under higher $\mathrm{Cd}$ concentration in soils (Fig. 3). The relative abundance of Actinobacteria was significantly decreased and Proteobacteria was significantly increased in the $B$. napus rhizosphere bacterial community. This is in agreement with Wu et al. (2018) who found that Actinobacteria abundance was significantly decreased under Cd stress, with a increase of Proteobacteria.

$\mathrm{Cd}$ pollution could change the relative abundance on genus level (Fig. 4B) including Sphingomonas sp., Lysobacter sp., and Ralstonia sp. which increased with the increase of $\mathrm{Cd}$ levels and these genera could resist $\mathrm{Cd}$ pollution (Guo et al. 2017; Nies 2000; Tipayno et al. 2018). Additionally, the relative abundance of Gemmatimonas sp., Arthrobacter sp., Haliangium sp., and Terriglobus sp., decreased with increasing Cd concentration. The increase of resistant groups and the reduction of sensitive groups might cause the change (Singh et al. 2014).

Results from dissimilarity tests and PCoA indicated that the soil bacterial community structures were obviously altered under the higher $\mathrm{Cd}$ concentration (30 mg/kg) (Additional file 1: Table S14 and Table S15; Fig. 5B). Hou et al. (2018) found that $\alpha$-diversity was 
significantly decreased and bacterial community structure was altered in rice when $\mathrm{Cd}$ levels were elevated. Wood et al. (2016) also found that Cd significantly changed bacterial community structure with no reduction in bacterial number in the $\mathrm{Cd}$-accumulating plant. Results of Mantel test, CCA, and CCA-based VPA (Table 1; Fig. 6; Additional file 1: Table S18, Figure S7) suggested the bacterial community in soil samples is most significantly and negatively correlated with $\mathrm{Cd}$ stress, which was in accordance with previous findings (Beattie et al. 2018).

There were no significant effects to the bacterial $\alpha$-diversity or community structure under $10 \mathrm{mg} / \mathrm{kg} \mathrm{Cd}$ stress in soils, possibly due to the presence of the oilseed rapes. Wang et al. (2018) found that Cd stress reduced microbial $\alpha$-diversity, while planting with oilseed rape increased the microbial $\alpha$-diversity, alleviating the toxic effects of $\mathrm{Cd}$ in soils. The result revealed that both of $B$. napus and $B$. junca could reduce the toxicity of $\mathrm{Cd}$ to bacteria.

Although many studies have concerned the influence of $\mathrm{Cd}$ on soil microbial communities, less research has paid attention on plant microbial community (phyllospheric and endophytic) affected by contaminant. The phyllosphere and endosphere bacteria are important in remediation of heavy metal pollutions (Jia et al. 2018; Wang et al. 2020b) and some of them could promote the plant growth (Bulgarelli et al. 2013). In this study, there are almost no significant variation for plant bacterial community diversities and structure (phyllospheric and endophytic bacterial community) under Cd stress (Additional file 1: Figure S4), but Cd contamination could change the relative abundance of some genera (Fig. 4A). Some of these bacteria had reported that are beneficial for soilplant ecosystems. For example, Ralstonia sp. and Methylobacterium sp. were Cd-resistant bacteria (Lodewyckx et al. 2002; Nies 2000). The variation of the above bacteria under $\mathrm{Cd}$ imposition may lead to the change of the ecological function in the soil-plant ecosystem.

This study demonstrated the effect of $\mathrm{Cd}$ on the soilplant ecosystem. Cd suppressed the growth of oilseed rapes (B. napus and B. juncea) and the physiological traits of plants were changed under $\mathrm{Cd}$ stress. Meanwhile, $\mathrm{Cd}$ primarily affected $\mathrm{pH}$ and nitrogen in soil physicochemical properties. Accumulation of $\mathrm{Cd}$ in plants increased and TF was decreased with increasing $\mathrm{Cd}$ level in soils, and both $B$. napus and B. juncea were accumulators for $\mathrm{Cd}$ because of BAF higher than 1 . The bacterial communities in soil were significantly altered under higher $\mathrm{Cd}$ treatments while no significant difference was found for plant bacterial community. Additionally, B. juncea may have stronger $C d$ tolerance than $B$. napus under higher $\mathrm{Cd}$ concentration. This research offers a new perspective for the impact of contaminants on soil-plant system and might be help improve phytoremediation efficiency.

\section{Supplementary Information}

The online version contains supplementary material available at https://doi. org/10.1186/s13568-021-01264-y.

Additional file1. Additional data.

\section{Acknowledgements}

The authors are thankful to School of Life Sciences, Hunan University of Science and Technology and Key Laboratory of Environmental Biotechnology, Research Center for Eco-Environmental Sciences, Chinese Academy of Sciences for their support in this experiment.

\section{Authors' contributions}

DJ and MY conceived the experiments. YD, DaZ and DiZ designed the experiments. YD, DaZ and JW performed the experiments. YD, DiZ, JW, LL and $\mathrm{HC}$ analyzed the data. YD, wrote the paper and DaZ with MY revised and perfected the paper. All authors have read and approved the final manuscript.

\section{Funding}

This work was supported by National Key Research and Development Program of China (No. 2018YFD1000904), the Scientific Research Fund of Hunan Provincial Education Department (No. 17K035), the opening funding of Hunan Key Laboratory of Economic Crops Genetic Improvement and Integrated Utilization (No. E22011), Guangxi Key Laboratory of Biology for Crop Diseases and Insect Pests (No. 2019-KF -03) and the opening funding of Jiangsu Key Laboratory for Food Quality and Safety-State Key Laboratory Cultivation Base, Ministry of Science and Technology (No. 028074911709).

\section{Availability of data and materials}

The authors declare that all data obtained have been included into the manuscript and its additional files.

\section{Declarations}

\section{Ethics approval and consent to participate}

This article does not contain any studies with animals performed by any of the authors. Informed consent was obtained from all individual participants included in the study.

\section{Competing interests}

The authors declare that they have no confict of interest.

\section{Author details}

${ }^{1}$ School of Life Sciences, Hunan University of Science and Technology, Xiang$\tan 411201$, People's Republic of China. ${ }^{2}$ Key Laboratory of Environmental Biotechnology, Research Center for Eco-Environmental Sciences, Chinese Academy of Sciences, Beijing 100085, People's Republic of China. ${ }^{3}$ Hunan Key Laboratory of Economic Crops Genetic Improvement and Integrated Utilization, Xiangtan 411201, People's Republic of China. ${ }^{4}$ Guangxi Key Laboratory of Biology for Crop Diseases and Insect Pests, Plant Protection Research Institute, Guangxi Academy of Agricultural Sciences, Nanning 530007, People's Republic of China.

Received: 1 February 2021 Accepted: 3 July 2021

Published online: 10 July 2021

\section{References}

Beattie RE, Henke W, Campa MF, Hazen TC, McAliley LR, Campbell JH (2018) Variation in microbial community structure correlates with heavy-metal contamination in soils decades after mining ceased. Soil Biol Biochem 126:57-63 
Beckers B, Op De Beeck M, Thijs S, Truyens S, Weyens N, Boerjan W, Vangronsveld J (2016) Performance of $16 \mathrm{~S}$ rDNA primer pairs in the study of rhizosphere and endosphere bacterial microbiomes in metabarcoding studies. Front Microbiol 7:650

Belimov AA, Safronova VI, Demchinskaya SV, Dzyuba OO (2007) Intraspecific variability of cadmium tolerance in hydroponically grown Indian mustard (Brassica juncea (L.) Czern.) seedlings. Acta Physiol Plant 29(5):473-478

Bradford MM (1976) A rapid and sensitive method for the quantitation of microgram quantities of protein utilizing the principle of protein-dye binding. Anal Biochem 72:248-254

Bulgarelli D, Schlaeppi K, Spaepen S, Loren V, van Themaat E, Schulze-Lefert P (2013) Structure and functions of the bacterial microbiota of plants. Annu Rev Plant Biol 64:807-838

Cheraghi-Aliakbari S, Beheshti-Alagha A, Ranjbar F, Nosratti I (2020) Comparison of Myagrum perfoliatum and Sophora alopecuroides in phytoremediation of $\mathrm{Cd}$ - and $\mathrm{Pb}$-contaminated soils: a chemical and biological investigation. Chemosphere 259:127450

DalCorso G, Fasani E, Manara A, Visioli G, Furini A (2019) Heavy metal pollutions: state of the art and innovation in phytoremediation. Int J Mol Sci 20(14):3412

Deng S, Ke T, Li L, Cai S, Zhou Y, Liu Y, Guo L, Chen L, Zhang D (2018) Impacts of environmental factors on the whole microbial communities in the rhizosphere of a metal-tolerant plant: Elsholtzia haichowensis Sun. Environ Pollut 237:1088-1097

Dubois M, Gilles KA, Hamilton JK, Rebers PA, Smith F (1956) Colorimetric method for determination of sugars and related substances. Anal Chem 28:350-356

Edgar RC (2013) UPARSE: highly accurate OTU sequences from microbial amplicon reads. Nat Methods 10(10):996-998

Frey SD, Knorr M, Parrent JL, Simpson RT (2004) Chronic nitrogen enrichment affects the structure and function of the soil microbial community in temperate hardwood and pine forests. For Ecol Manag 196(1):159-171

Gascó G, Álvarez ML, Paz-Ferreiro J, Méndez A (2019) Combining phytoextraction by Brassica napus and biochar amendment for the remediation of a mining soil in Riotinto (Spain). Chemosphere 231:562-570

Ghyselinck J, Pfeiffer S, Heylen K, Sessitsch A, De Vos P (2013) The effect of primer choice and short read sequences on the outcome of 165 rRNA gene based diversity studies. PLoS ONE 8(8):e71360

Giansoldati V, Tassi E, Morelli E, Gabellieri E, Pedron F, Barbafieri M (2012) Nitrogen fertilizer improves boron phytoextraction by Brassica juncea grown in contaminated sediments and alleviates plant stress. Chemosphere 87(10):1119-1125

Goswami S, Das S (2015) A study on cadmium phytoremediation potential of Indian mustard, Brassica Juncea. Int J Phytoremediation 17(1-6):583-588

Guo H, Nasir M, LV J, Dai Y, Gao J (2017) Understanding the variation of microbial community in heavy metals contaminated soil using high throughput sequencing. Ecotoxicol Environ Saf 144:300-306

Hou D, Wang R, Gao X, Wang K, Lin Z, Ge J, Liu T, Wei S, Chen W, Xie R, Yang X, Lu L, Tian S (2018) Cultivar-specific response of bacterial community to cadmium contamination in the rhizosphere of rice (Oryza sativa L.). Environ Pollut 241:63-73

Jia T, Guo T, Cao M, Chai B (2018) Effects of heavy metals on phyllosphere and rhizosphere microbial community of Bothriochloa ischaemum. Appl Sci 8:1419

Jing R, Kjellerup BV (2018) Biogeochemical cycling of metals impacting by microbial mobilization and immobilization. J Environ Sci 66:146-154

Khan MA, Khan S, Khan A, Alam M (2017) Soil contamination with cadmium, consequences and remediation using organic amendments. Sci Total Environ 601-602:1591-1605

Kim J, Lee WJ, Vu TT, Jeong CY, Hong SW, Lee H (2017) High accumulation of anthocyanins via the ectopic expression of AtDFR confers significant salt stress tolerance in Brassica napus L. Plant Cell Rep 36(8):1215-1224

Kong Y (2011) Btrim: a fast, lightweight adapter and quality trimming program for next-generation sequencing technologies. Genomics 98(2):152-153

Kong X, Jin D, Jin S, Wang Z, Yin H, Xu M, Deng Y (2018) Responses of bacterial community to dibutyl phthalate pollution in a soil-vegetable ecosystem. J Hazard Mater 353:142-150

Li HX, Xiao Y, Cao LL, Yan X, Li C, Shi HY, Wang JW, Ye YH (2013) Cerebroside $C$ increases tolerance to chilling injury and alters lipid composition in wheat roots. PLoS ONE 8(9):e73380
Li Z, Ma Z, van der Kuijp TJ, Yuan Z, Huang L (2014) A review of soil heavy metal pollution from mines in China: pollution and health risk assessment. Sci Total Environ 468-469:843-853

Li Y, Wang S, Zhang Q, Zang F, Nan Z, Sun H, Huang W, Bao L (2018) Accumulation, interaction and fractionation of fluoride and cadmium in sierozem and oilseed rape (Brassica napus L.) in northwest China. Plant Physiol Biochem 127:457-468

Liu YT, Chen ZS, Hong CY (2011) Cadmium-induced physiological response and antioxidant enzyme changes in the novel cadmium accumulator, Tagetes Patula. J Hazard Mater 189(3):724-731

Liu H, Xie Y, Li J, Zeng G, Li H, Xu F, Feng S, Xu H (2020) Effect of Serratia sp. K3 combined with organic materials on cadmium migration in soil-vetiveria zizanioides L. system and bacterial community in contaminated soil. Chemosphere 242:125164

Lodewyckx C, Mergeay M, Vangronsveld J, Clijsters H, Van der Lelie D (2002) Isolation, characterization, and identification of bacteria associated with the zinc hyperaccumulator Thlaspi caerulescens subsp. calaminaria. Int J Phytoremediation 4:101-115

Lu M, Xu K, Chen J (2013) Effect of pyrene and cadmium on microbial activity and community structure in soil. Chemosphere 91(4):491-497

Magoč T, Salzberg SL (2011) FLASH: fast length adjustment of short reads to improve genome assemblies. Bioinformatics 27(21):2957-2963

Mitra S, Pramanik K, Ghosh PK, Soren T, Sarkar A, Dey RS, Pandey S, Maiti TK (2018) Characterization of Cd-resistant Klebsiella michiganensis MCC3089 and its potential for rice seedling growth promotion under $\mathrm{Cd}$ stress. Microbiol Res 210:12-25

Molnár Á, Papp M, Zoltán Kovács D, Bélteky P, Oláh D, Feigl G, Szőllősi R, Rázga Z, Ördög A, Erdei L, Rónavári A, Kónya Z, Kolbert Z (2020) Nitro-oxidative signalling induced by chemically synthetized zinc oxide nanoparticles (ZnO NPs) in Brassica species. Chemosphere 251:126419

Nies DH (2000) Heavy metal-resistant bacteria as extremophiles: molecular physiology and biotechnological use of Ralstonia sp. CH34. Extremophiles 4:77-82

Rattan RK, Datta SP, Chhonkar PK, Suribabu K, Singh AK (2005) Long-term impact of irrigation with sewage effluents on heavy metal content in soils, crops and groundwater-a case study. Agric Ecosyst Environ 109(3):310-322

Rizwan M, Ali S, Zia Ur Rehman M, Rinklebe J, Tsang DCW, Bashir A, Maqbool A, Tack FMG, Ok YS (2018) Cadmium phytoremediation potential of Brassica crop species: a review. Sci Total Environ 631-632:1175-1191

Rossi G, Figliolia A, Socciarelli S, Pennelli B (2002) Capability of Brassica napus to accumulate cadmium, zinc and copper from soil. Acta Biotechnol 22(1-2):133-140

Sarria Carabalí MM, García-Oliva F, Cortés Páez LE, López-Lozano NE (2020) Effect of cadmium contamination on the rhizosphere bacterial diversity of Echinocactus platyacanthus. Rhizosphere 13:100187

Schulz S, Brankatschk R, Dümig A, Kögel-Knabner I, Schloter M, Zeyer J (2013) The role of microorganisms at different stages of ecosystem development for soil formation. Biogeosciences 10(6):3983-3996

Singh BK, Quince C, Macdonald CA, Khachane A, Thomas N, Al-Soud WA, Sorensen SJ, He Z, White D, Sinclair A, Crooks B, Zhou J, Campbell CD (2014) Loss of microbial diversity in soils is coincident with reductions in some specialized functions. Environ Microbiol 16(8):2408-2420

Tipayno SC, Truu J, Samaddar S, Truu M, Preem JK, Oopkaup K, Espenberg M, Chatterjee P, Kang Y, Kim K, Sa T (2018) The bacterial community structure and functional profile in the heavy metal contaminated paddy soils, surrounding a nonferrous smelter in South Korea. Ecol Evol 8(12):6157-6168

Wang Q, Garrity GM, Tiedje JM, Cole JR (2007) Naïve Bayesian classifier for rapid assignment of rRNA sequences into the new bacterial taxonomy. Appl Environ Microbiol 73(16):5261-5267

Wang X, Bai J, Wei T, Feng G, Zhao H, Wei W, Wang M, Zhao Y (2018) Oilseed rape cultivation increases the microbial richness and diversity in soils contaminated with cadmium. J Soils Sediments 18(7):2451-2462

Wang P, Peng H, Liu J, Zhu Z, Bi X, Yu Q, Zhang J (2020a) Effects of exogenous dissolved organic matter on the adsorption-desorption behaviors and bioavailabilities of $\mathrm{Cd}$ and $\mathrm{Hg}$ in a plant-soil system. Sci Total Environ 728:138252

Wang Q, Ge C, Xu S, Wu Y, Sahito ZA, Ma L, Pan F, Zhou Q, Huang L, Feng Y, Yang X (2020b) The endophytic bacterium Sphingomonas SaMR12 alleviates $\mathrm{Cd}$ stress in oilseed rape through regulation of the GSH-AsA cycle and antioxidative enzymes. BMC Plant Biol 20(1):63 
Wood JL, Zhang C, Mathews ER, Tang C, Franks AE (2016) Microbial community dynamics in the rhizosphere of a cadmium hyper-accumulator. Sci Rep 6:36067

Wu B, Hou S, Peng D, Wang Y, Wang C, Xu F, Xu H (2018) Response of soil micro-ecology to different levels of cadmium in alkaline soil. Ecotoxicol Environ Saf 166:116-122

Xia C, Luo Y, Yao J, Liu W, Wang F, Wu X (2018) Joint effects of Cd and thioglycollic acid on soil microbial activity. Int Biodeterior Biodegradation 128:164-170

Zeng X, Zou D, Wang A, Zhou Y, Liu Y, Li Z, Liu F, Wang H, Zeng Q, Xiao Z (2020) Remediation of cadmium-contaminated soils using Brassica napus: effect of nitrogen fertilizers. J Environ Manage 255:109885
Zhang WH, Huang Z, He LY, Sheng XF (2012) Assessment of bacterial communities and characterization of lead-resistant bacteria in the rhizosphere soils of metal-tolerant Chenopodium ambrosioides grown on lead-zinc mine tailings. Chemosphere 87(10):1171-1178

\section{Publisher's Note}

Springer Nature remains neutral with regard to jurisdictional claims in published maps and institutional affiliations.

\section{Submit your manuscript to a SpringerOpen ${ }^{\circ}$ journal and benefit from:}

- Convenient online submission

- Rigorous peer review

- Open access: articles freely available online

- High visibility within the field

- Retaining the copyright to your article

Submit your next manuscript at $\boldsymbol{\nabla}$ springeropen.com 